\title{
Participation of Educational Institutions in Supporting Halal Tourism Destination Program through Development of Local Culture in East Lombok Regency
}

\author{
${ }^{*}$ Fitriani ${ }^{1)}$ and Yurni Suasti ${ }^{2)}$
}

1) Student Geography of Science, Padang State University, INDONESIA

2) Department of Geography, Universitas Negeri Padang-INDONESIA

Email: renoysari@gmail.com

*Corresponding Author, Received: January 15, 2018, Revised: March 02. 2018, Accepted: May 20, 2018

This is an open acces article distributed under the Creative Commons 4.0 Attribution License, wich permits unrestricted use, Distribution, and reproduction in any medium provided the original work is properly cited @2017 by author and Universitas Negeri Padang

\begin{abstract}
The purpose of this study is to obtain information about the participation of educational institutions in supporting Halal Tourism destination through development of local culture. This study uses qualitative descriptive approach by using observation, interview and questionnaire in data collection. Subjects to be studied in this study are head of education department, principal (SMAN 1 Rujukan Selong) and random people in the community. Sample is determined by purposive sampling technique to select school and proportional random sampling technique to select respondent. Study finding obtained from formal institutions: 1) good example from teacher as a model in character education, 2) curriculum that contain Halal Tourism, 3) contribution in improvement and maintenance of tourism facilities and infrastructures in location of tourism attractions, 4) held a parade on Islam holiday (PHBI) and Islamic art contest. Meanwhile, non-formal participations are: 1) construction of religious facilities, 2) selling halal food products in area of tourist attraction, 3) selling Islamic souvenirs.
\end{abstract}

Keywords: Participation of Education Institution, Local Culture, Halal Tourism.

\section{Introduction}

Religious tourism and spiritual motivation have spread widely and become popular in recent decades, which occupy an important segment of international tourism and have grown substantially in recent years. People who involved in Halal Tourism service is emphasizing the fact that any strategy or product must be guided by Islamic law (sharia) (Batour et al., 2015). The increasing of interest in Halal Tourism is partly due to the growth of Muslim populations around the world. Halal Tourism is a new concept in the tourism industry. There is a need to develop more Halal Tourism products and services to meet this dynamic and growing market (Chookaew et al., 2015 in Henderson, 2010).

Halal Tourism is "a tourist attraction or action that is permissible according to Islamic religion that used or practiced by Muslim in tourism industry". The definition strongly considers Islamic law (sharia) as the basis for delivering tourism products and services to target customers who are primarily Muslim. It claimed that location of the activity is not limited to Muslim countries. Therefore, it includes services and products that designed for Muslim travelers in Muslim and non-Muslim countries. In addition, the definition assumes that purpose of journey is not necessarily religious. This may be one of the common motivations of tourism (Battour et al., 2015). 
Formal education in accordance with a systematic and organized education model is organized and managed in accordance to the existing set of laws and norms and presenting a rigid curriculum in the purpose, content and methodology (Zaki, 1988). There is also a definition of educational institution as public education where the organization is local and fragmented that motivating children to succeed in learning activities (Karpov, 2017). Non-formal education is an education outside formal education that can be implemented in a structured and tiered manner, organized for citizens who need educational services that serve as a substitute, enhancement, and/or complementary of formal education in order to support continuous education. According to Zaki (1988) non-formal education seems better to meet the individual need of student, because non-formal education includes education of skill, early childhood education, youth education, women's empowerment education, literacy education, literate education, and vocational training and can be a source of income for some people.

According to Brennan (2009), the concept of local culture has many definitions and point of views. The social side, it usually widely interpreted in ways of life including law, values and good behavior. Basically, culture can be seen as universal thinking. This thinking is patterned from time to time so it becomes a habit in a particular society. Furthermore, Brennan also said that local culture becomes an identity for a society. This identity includes general understanding, habits, and values. Judistira (2008) says that local culture is not only revealed from art performance and statement, but it is including all forms and ways of behaving, acting, and mind-patterns inside what it appears to be.

According to Astuti (2009), participation is the involvement of a person or several people in an activity. Involvement can include mental, emotional and physical in using all capabilities (initiative) in activities and support the achievement of objectives and responsibilities in each activities. Others argue that participation is the inclusion of thought and emotion of worker into group situation and take responsibility in the group (Zamani et al. 2009). Participation also defined as "a natural process in which people, including disadvantaged people (income, gender, ethnicity, education) influence or control a decision-making that directly concerning their live" (Narayan, 1997). So participation is the mental and emotional involvement of a person in a group situation that encourages them to support the achievement of the group's goals and take responsibility for the group. With participation, it will increase the capability (empowerment) of everyone involved either directly or indirectly in a development program by involving them in decision making and further activities for long term (Chookaew, 2015). This educational institution is expected to provide participation and policies that is need so that people can live to face future. Likewise, educational institutions, both schools and related agencies in East Lombok regency, certainly have participation to support Halal Tourism programs that are being developed in present time. Based on previous background, the purpose of this study is to investigate the participation of educational institutions in supporting Halal Tourism programs in East Lombok regency.

\section{Method}

The type of this research is descriptive research with qualitative approach method. The result of this research is described clearly and in detail which is to give a comprehensive picture about the participation of educational institution in supporting Halal Tourism programs through the development of local culture. Data is divided in two group that are primary data and secondary data which is analyzed using qualitative analysis. Secondary data is needed in this research that is data that related to the form of education institute's participation in East Lombok Regency. In addition, primary data is also used. The techniques used in primary data collection are interview and observation techniques. Informants in this research are determined by Purposive Sampling, in which the sample is not intended to represent the population, but to represent information. 


\section{Results and Discussion}

\section{Participation of Formal Education Institutions in Supporting Halal Travel Destination Program Teacher (Tuan Guru) paragon as a model of character education}

Teacher (Tuan Guru) in Sasak society's perspective is not merely a hajj (Tuan) who teaches (teacher), but a figure that has deep knowledge and exemplary behavior that becomes the center of reference for society. In the context of Sasak community, Teachers are also Kyai, but not all Kyai are Teacher. The social changes made by Tuan Guru in Lombok are evolutionary from recitation, majlis taklim (religious assembly), and pesantren or madrasah (Islamic school) (Battour, 2016). In the context of Lombok society, one of agent of change or leader for social change is Tuan Guru. He is a figure who plays an important role in social changes in Lombok Society. Tuan Guru is a public figure who has a role in all area of life, so that it gives him position as a central figure in Lombok society.

In East Lombok regency, Tuan Guru has a very important role in the field of education, but not in practical politics. Tuan Guru is charismatic in East Lombok regency's society, so the community is highly respecting them. Tuan Guru is often present in events that held by education office and schools in East Lombok regency. Tuan Guru can provide motivation for students in activities of school competition. Usually the speech, deeds and behavior of Tuan Guru is respected and enviable for people in East Lombok.

\section{Curriculum with Halal Tourism content}

Basically, curriculum serves as a guide or reference. For teacher, curriculum serves as a guide in implementing the learning process. For principal and supervisor, curriculum serves as a guide in supervision. For parent, curriculum serves as a guide in guiding their children to study at home. For community, curriculum serves as a guide to provide assistance for implementation of education process in school. And for student, curriculum has a function to learn subject. Curriculum is a reference for subject matter (Jalal, 2001)

There is content of Halal Tourist attraction in curriculum at Lombok's public school, so that students can better understanding the Halal Tourism and they can realize and apply in their daily life. According to Mr. Abdul Hakim (vice principal of public relation) at SMA N 1 Selong, Halal Tourism content is preferred in subjects of English and Arabic. This is certainly very supportive for students to become a tour guide for tourist that visiting the island. Also, this curriculum contains traditional handicraft and entrepreneurship in Islamic nuance, in order to motivate students to conduct useful activities in supporting the success of Halal Tourism programs in East Lombok regency.

\section{Contribution in the improvement and maintenance of tourism facilities and infrastructures}

Tourism facilities and infrastructure is a complementary tourist destination that is needed to serve tourist's needs so that they can enjoy the tour. Tourism facility as a spearhead in tourism business can be defined as an effort that directly or indirectly provide services to tourists in tourist destination area where its existence is very dependent on the existence of tourism activities (Fajriah, 2014)

Tourism facilities and infrastructure are very important in the field of tourism. Facilities and infrastructures that tourists need are to facilitate and provide information about tourism attraction. These facilities and infrastructure should be maintained as good as possible. Boy/girl scout activities often conduct improvement and maintenance of tourism facilities and infrastructures. The activities of these students include: repairing the direction sign in tourist area, improving maps of tourist objects in East Lombok, watch over parking lot at certain times, communal sanitizing by students at tourism area and keep clean the area of mosque.

\section{Arrange parade in Islamic holiday (PHBI) and Islamic Art Contest}

The Islamic Holiday (PHBI) is an activity to commemorate Islamic festal-day with the intention to spread Islam and to explore the meaning of it in Islam religion. In East Lombok Regency to explore the meaning of Islamic Day there is some attractions for tourists who visit the island. According to Darmawan as a student in SMA N 1 Selong, the activities of Islamic day commemoration is conducted by arranging a unique parade 
and highlighting Halal Tourism in East Lombok. The parade is held in ceremonies such as Maulid Nabi (Prophet Muhammad birthday), Isra' Mi'raj and Islamic New Year or Muharram 1st (Islamic calendar). As the branding of sharia tourism in East Lombok, local government of Lombok Regency gives efforts and cooperates with education institutions to involve students in parade participation by designing branding of Islamic tourism. To strengthen the position as World's Best Halal Tourism, West Nusa Tenggara (NTB) province held a festival event and produce innovative Halal Tourism products that are intensively conducted by NTB Provincial Government. After successfully held the event of Qur'an Reading Competition (MTQ) in National Level, Department of Culture and Tourism of NTB Province also held Lombok's Religious Art Performance (BBLS) that located at Islamic Center of Mataram. In this event, there is the appearance of Islamic arts (Hadrah, Marawis, Rebana Burdah, Qasidah, and Reban Lima), Zikir Zaman (Islamic worship), and others. It is supporting Lombok as tourist destination area for halal tourism. Therefore, schools need to prepare for BBLS activity to gain more tourists.

\section{Participation of Non-Formal Education Institutions in Supporting Halal Tourism Destination Program Development of religious facilities}

Access to worship is the most important in the development of Halal Tourism. Tourists while doing tourism activities can also easily carry out its obligations as a Muslim that is to pray five times. In Lombok, access to pray is very good because there are over 4,500 mosques spread across 598 villages in Lombok Island. Island of a thousand mosques is an epithet for Lombok Island. The number of mosques in Lombok can also be a tourist destination, because some mosques in Lombok Island have historical value. Like the Karang Bayan Mosque, the Bayan Mosque and several other mosques. The majority of inhabitants in this Lombok Island develop an easy access to prayer where there is a mosque in three to seven kilometers of the island, which has an area of 2.7 million square kilometers with 90 percent of population is Muslims. In addition to mosques, access to worship can also be found in tourist areas, usually there are small booths provided by surrounding community to provide facilitation, and hotel owners provide access to worship services such as Kiblat (direction of Islamic pray), prayer facilities, Al-Qur'an and other worship facilities. Shopping malls in Lombok also have religious facilities, such as Lombok Epicentrum Mall (LEM) providing mukenah and sarong (prayer facilities), Al-Qur'an, and mosque keeper to support facilities such as toilets, and ablution facilities. There is a big mosque that can accommodate $400 \mathrm{Jamaah} /$ prayer (At-Taqwa LEM Mosque) which also conducted Friday prayer. The convenience of the mosque will give pleasant for visitors in performing the worship. As an area that has the nickname "the country of a thousand mosques", it is very clear that Lombok has beautiful mosque buildings which are clean and comfortable and provide peace for visitors in worship.

\section{Selling halal food products in the area of tourist attraction}

The most important and fundamental is the need for food and beverages that are guaranteed to be halal by the authorized institution, because food and drink is the basic need of every human being for survival. NTB Provincial Tourism Office has prepared the facilities for Halal Tourism such as halal certification so that Muslim tourists are guaranteed to consume halal food by authorization from Majelis Ulama Indonesia/MUI (Indonesian Islamic Scholar) and regulated in Governor Regulation number 51 of 2015 About Halal Tourism, and also Local Regulation number 2 of 2016 About Halal Tourism. With the certification of halal products by LPPOM MUI NTB (MUI laboratory), it gives conviction for tourists about the halal of food and beverages in Lombok and products can be consumed by Muslim because it is acceptable in Islamic religion. The most important thing to remember that halal certification service is not only destined for Muslim tourists, but non Muslim tourists also can use it. According to Mr. Sofyan, all foods that he sells is labeled halal. In this case, the community sells traditional food of Lombok to support tourism in East Lombok. Besides, it is also necessary to perform exhibition for traditional halal food that can be conducted by community organizations in tourism area to support community empowerment program based on Halal Tourism in East Lombok. 


\section{Islamic souvenirs}

One of businesses that rely on high creativity is souvenir business. The required material is simple and even used goods can be transformed into souvenir. Souvenir is a term to goods that become a reminiscence or reminder of a place or event that is historic or important for someone. Souvenir sale is a growing business around tourism areas. Souvenirs usually small size for family or friends with unique shape and most importantly the price is relatively cheap so it can be purchased with a lot of quantity. Souvenirs from tourism areas are usually typical items of the place or describing the area. Souvenirs in tourism area of East Lombok are made from simple materials such as wooden key-chains, t-shirts, handicrafts, and Lombok woven fabrics that have high quality. By looking at the souvenirs, it can also be used as a media promotion for tourist destination.

\section{Conclusion}

Halal Tourism in Indonesia has good economic prospects as part of national tourism industry. This tourism industry is aimed not only to provide material and to fulfill psychological aspect for tourists, but also to give contribution for the increasing of government revenue. This Halal Tourism is not exclusive, but inclusive for all travelers (Muslim and Non-Muslim). The essence of Halal Tourism emphasizes the principles of sharia in the management of tourism and hospitable and friendly services for all tourists in Lombok Island. Therefore, to realize Indonesia as the world's Halal Tourism destination, its development strategy is aimed at fulfilling the tourism competitiveness index as its main indicators and reforming the infrastructure, promotion, preparation of human resources, especially the enhancement of tourism business's capacity. Educational Institutions is the most appropriate organization in providing support to promote Halal Tourism in East Lombok. The participation of educational institutions in supporting the Halal Tourism program is developed through local community culture. Because, the involvement of local culture, it will increase the awareness of the community to sustain Halal Tourism program in Lombok Island.

\section{References}

Battour M, Mohd Nazari Ismail. (2015). Halal tourism: Concepts, practises, challenges and future, Jurnal TMP00219; No of Pages 5, ELSAVIER

BPS. (2014). Kabupaten Lombok Timur dalam Angka. Pemkab. Lombok Timur

Brennan, Mark A., Courtney G. Flint, and A. E. Luloff. (2009). Bringing together local culture and rural development: Findings from Ireland, Pennsylvania and Alaska. Sociologia ruralis 49.1 : 97-112.

Chookaew, Sureerat, Oraphan chanin, Jirapa Charatarawat, Pingpis Sriprasert, and Sudarat Nimpaya. (2015). Increasing Halal Tourism Potential at Andaman Gulf in Thailand for Muslim Country. Journal of Economics, Business and Management, Vol. 3, No. 7, July 2015

Fajriah, S. D. (2014). Pengembangan Sarana dan Prasarana untuk Mendukung Pariwisata Pantai yang Berkelanjutan (Studi Kasus: Kawasan Pesisir Pantai Wonokerto Kabupaten Pekalongan). Jurnal Pembangunan Wilayah \& Kota, 10(2), 218-233.

Jalal, Fasli. Supriadi, Dedi, (2001). Reformasi Pendidikan dalam Konteks Otonomi Daerah, Depdiknas, Jakarta : Adicitakaryanusa

Henderson, J.C. (2010). Sharia-Compilant Hotels. Tourism and Hospitality Research, 10, 246-254.

Karpov, Alexander. (2017). Early Engagement of Schoolchildren in Research Activities: The Human Factor. International Conference on Applied Human Factors and Ergonomics. 978-3-319-60017-8 DOI: 10.1007/978-3-319-60018-5_9

Narayan-Parker, D. (1997). Voices of the poor: poverty and social capital in Tanzania (Vol. 20). World Bank Publications. 
Astuti, Siti Irene D. (2009). Desentralisasi dan Partisipasi dalam Pnedidikan. Yogyakarta: UNY

Undang-undang Republik Indonesia,No. 20 Tahun 2003 tentang Sistem Pendidikan Nasional dan Penjelasannya, Pen. CV Aneka Ilmu, cet. 1 tahun 2003.

Zaki, D.C,. (1988). Formal, non-formal and informal education: Concepts/applicability. AIP Conference Proceedings, 173 doi : 10.1063/1.37526

Zamani-Farahani, H., and Henderson, J. C. (2009). Islamic tourism and managing tourism development in Islamic societies: The cases of Iran and Saudi Arabia. International Journal of Tourism Research, $12(1)$. 